\title{
NETWORK, HOW? Perceptions of business people on networking practices
}

\author{
Saskia de Klerk: North West University \\ Minrie Greeff: Noth West University
}

\section{SYNOPSIS}

Purpose: The purpose of this paper was to contribute to literature on networking from a South African perspective. Literature on networking is mainly concentrated on the European and American contexts with homogeneous groups and traditional divisions. The business landscape of South Africa thus requires more investigation.

Problem investigated: Literature regarding networking in an South African context with its dynamic business environment is limited. This article addresses the concerns of how South African business owners and managers perceive networking in their businesses and specifically focus on the South African perspective. Therefore, the focus is on the perceptions of business owners and managers on current networking practices in South Africa.

Methodology: A qualitative research design to uncover the rich underlying feelings of business owners and managers was used. The qualitative enquiry consisted of five focus group discussions ( $n=41$ participants) among prominent business owners and managers in the Gauteng Province, South Africa. The Gauteng Province was selected since it is the economic and innovation hub of South Africa.

Findings and implications: The main findings showed the following main themes of networking that emerged from the data, and included (1) networking as a skill versus a natural ability; (2) the motivation behind networking; (3) the loci of networking; (4) the type of relationships that determine the character of the network; and (5) the relationship characteristics of successful networking. The main contribution of this is that there seems to be different networking situations and applications for different circumstances. According to the participants, it seems that networking in the South African landscape appears to be either relationship or business based.

Originality and value of the research: The value of these findings lies in the fact that they contribute to networking literature from a South African perspective and that networking skills form an important part of management and entrepreneurship. The conclusion is that this research supports the notion that networking skills are important and should be developed on a wider basis. Formal courses on networking or incorporation in existing management training and development courses need to be implemented on all levels by educational institutions and government.

Keywords: networking, business managers, business owners, perceptions, relationships

\section{INTRODUCTION AND PROBLEM STATEMENT}

All economic activity is made possible by the communication and building of relationships between different networks. The nodes in the relationships may include friends, family, mentors, colleagues and investors (Jones \& Tilley, 2003:17). Business is conducted in an environment of indirect and direct relationships, which makes it complex and interconnecting (Bridgewater \& Egan, 2002:21). The entrepreneur or business manager is expected to have networking skills to reach out from his or her sometimes-isolated business environment and to establish and maintain business relationships with others (Cohen \& Prusak, 2001:54). These networking relationships can assist the entrepreneur or business manager to increase productivity levels, reduce costs and expand his or her business operations by gaining exposure to new ideas and ways of doing business (Boe, 1994:2). Therefore, being part of a network offers the advantage that the business's competitiveness can be increased 
with the access to economies of scale, lower switching costs, and product differentiation, for example (Czerniawska \& Potter, 1998:26).

At an individual level, networking skills can also contribute to the success of the entrepreneur or manager in his or her personal capacity by providing the opportunity to keep a wide and balanced amount of relational capital (Grandori, 1999:288). In addition, the ability to communicate effectively with business partners, suppliers, customers and other role-players can be enhanced (Darley, 2003:1).

Strong established networking relationships make it easier for the entrepreneur or manager to collaborate successfully in business exchanges, which are of critical importance to exchanging the correct information, lowering risks and boosting rewards, as well as offering the opportunity to successfully negotiate and work together (Moberg \& Speh, 2003:1). The emphasis on the skills of an entrepreneur or manager to establish collaborative alliances is becoming more important. These collaborative relationships are sometimes developed through standardisation and in the development of specific structures, but mostly they are developed through informal relationships (Cross, Liedtka \& Weiss, 2005:124).

Networking is a crucial, dynamic and evolving part of a business (Boe \& Youngs, 1989:1). The success of networking lies in the way in which the relationships are managed. There are different levels of relationships and each one must be managed appropriately. Networking is also viewed as linked to the individual and his or her approach to networking (Bridgewater \& Egan, 2002:10-11). Therefore, the application of networking might be unique for every situation (Bridgewater \& Egan, 2002:33).

There has been an increasing amount of networking research internationally, particularly in management, with the main streams of research focusing on social capital, embeddedness, network organisations and organisational networks, board interlocks, joint ventures and inter-firm alliances, knowledge management, social cognition and group processes (Borgatti \& Foster, 2003). Literature distinguishes between structuralist and connectionist approaches to networks. The structuralists focus on the actual structure of the network or a formal fixture. The connectionist approach focuses on the networkers' networking or actions in the network (Brass, Galaskiewicz, Greve \& Tsai, 2004:795).

The South African networking perspective and context have not been researched for the broader community. The only evidence of networking research that could be found was for selected industries or community groups, for example the Indian community in the Gauteng Province (Bawa, 2006), intraand inter-organisational networking in terms of the 2010 Soccer World Cup (Denner \& Oosthuizen, 2008), the role of social networks in community reform (Pillay, 2004), inter-firm learning networks (Morris, Bessant \& Barnes, 2006) and business networking within a South African context (De Klerk \& Kroon, 2007).

Focused research is required that investigates and explains the applied networking practices of business managers and owners within a South African context. Therefore, this study seeks to extend the literature on this topic and contribute to ideas on the development of networking skills in businesses and among managers from diverse backgrounds. The aim of this study is to investigate the perceptions of business owners and managers and to formulate guidelines for networking practices in South Africa. This includes business owners and managers' perceptions on the necessity of networking, the way to network and what is necessary for networking success. 


\section{LITERATURE REVIEW}

The literature review presents an overview of networking as evidenced in the available literature. In this literature overview, issues such as the nature of networking, the motivation behind networking, the formal or informal orchestration of networking, different networks and associated activities, as well as the characteristics of successful networking will be discussed.

\section{Networking as a Natural Ability or Skill}

Networking is the natural tendency for an individual to treat others as he or she would like to be treated (Misner \& Morgan, 2000:25). In order to be successful and live a balanced life, an individual needs to be connected to other successful and balanced individuals (Lindsay, 2005:18). The nature of networking rests upon the motivation of the individual to acquire what he or she needs or wants from the other person, and he or she thus networks in order to obtain what he or she needs or wants. Therefore, the reason for an individual's decision to start networking is that he or she wishes to optimise his or her own position. This implies that the value gained from the network must compensate for the effort put into the network (Visagie, 2006).

Different personality types will follow different approaches in business networking. Each person will have a unique style and application, and create a unique self-brand (Nierenberg, 2005:viii).

\section{Motivating Factors that Drive Networking}

The main motivating factor for networking appears to be the exposure that is gained by meeting new and increasingly more people (Tomak \& Keskin, 2008). The exposure of an individual's business may lead to increased profits, and the increased human interaction may lead to the sharing of increased information and valuable experiences. Networking can provide support, safety, motivation, and a forum through which to share information and knowledge and develop commitment (Anderson, 2008:52). Networking with external role-players in the business environment may lead to repeat transactions in the form of referrals and access to a larger customer base (Templeton, 2003:27).

Mutually beneficial relationships can be built by combining the efforts, information and access to opportunities of different networking partners. This combined effort may lead to much higher results than by a single business in terms of creating jobs and developing local economies (Lipnack \& Stamps, 1993:5), in order to build a stronger competitive advantage (Kay, 2004:2) and achieve higher levels of efficiency (Gemünden, Ritter \& Walter, 1998:201). The substance of networks lies in that they exist; they cannot be measured merely based on the monetary outcome of a transaction. Networks therefore can be measured as successful once important role-players are included and the different role-players link their activities together by either combining resources to develop a competitive advantage or by making their own networks available (Ford, 1998:42-43).

Therefore, business relationships are used to access information and resources and this will be influenced by networkers' positions in the network and their access to social capital in the form of social relationships. This social capital is built on trust, commitment, reciprocity, expectations, and shared rules and obligations (Frazier \& Niehm, 2004:25). Social capital can be described as interpersonal friendship or family networks to which an individual has access. These connections are proven to place an individual in a better position to seek references or work, or learn to fulfil the requirements of his or her job. Therefore, the more connections an individual has, the better his or her chances of success are (Kerbo, 2006:397).

\section{Informal or Formal Orchestration of Networking}

A specific relationship can be based on what an individual brings to the relationship and what he or she wishes to receive from it. This exchange can take place formally or informally in terms of business and social needs (Bridgewater \& Egan, 2002:35). Relationships as an asset to business can be 
included in issues of sociability, reciprocity and trust, and can be found in both informal and formal social relations (Koniordos, 2005:3).

Sociability includes the filling of structural gaps, and an individual needs to foster formal relationships with people outside of their normal domain of thinking and challenge themselves in terms of adaptability and working outside of their comfort zone (Casciaro \& Lobo, 2005:96). The more informal the agreement, the more flexible the approach, and this enhances the opportunity for the development of relationships (Van Winkelen, 2003).

Reciprocity is based on the principle that an individual must give to receive and networking must thus be mutually beneficial (Lindenfield \& Lindenfield, 2005:75). These exchanges can include explicit and direct exchanges of favours or indirect and unconscious generosity (Moyer, 2005:160). The intent of the gift is the most important factor of reciprocity not to expect something in return (Misner \& Morgan, 2000:17). While such exchanges may be formally structured, information and communication technologies can be used to simplify the organising and maintenance of certain relationships. Every networker, however, needs to develop his or her own approach and unique style of networking in order to be successful (Taylor, 2006:146).

The basis for the relationships is trust and mutual understanding. Occasionally, the membership of a network can change and may include a variety of informal connections and relationships (Bridgewater \& Egan, 2002:132). Developing a rapport with members of the network and building trust in the relationship are very important to the success of the network (Taylor, 2006:146). Networks involve mutual understanding and an informal variety of connections and relationships with complementary strengths and fair exchangeable relations.

\section{There Appears to be Different Networks with Different Characteristics}

Various researchers have identified different types of networks, for instance business networking. Such networking appears to be focused on business activities (Hadjikhani \& Thilenius, 2005) and a nexus of business connections among individuals, the entrepreneur and embedded (indirect) relationships that stretch beyond the borders with customers, suppliers, and investors (Wickham, 2004:135). Other research includes networking in terms of work units or organisations (Brass et al., 2004:795), communities, colleagues, departments, teams, functions, offices, divisions, subsidiaries (Baker, 2000:viii) and other support figures, such as lawyers, accountants and banking personnel (Jones \& Tilley, 2003:20). All these relationships appear to be directed towards increasing business (White, 2004:5) through combined efforts (Crawford \& Hafsteinsson, 1996:235).

Social networking is described as the social relationships among people, including family relationships, friendships, and relationships among co-workers or information exchange (Garton, Haythornthwaite \& Wellman, 1997). Social networks are mostly focused on shared interests, such as sport, community service initiatives, interdepartmental developments or events, voluntary associations, charity events and fund-raising or profit teams (Uzzi \& Dunlap, 2005:56). Social networking relationships lend an individual life balance, support and motivation (Boe, 1994:9). Certain networking groups, such as elite social men's clubs, promote unity, class-consciousness and exclusivity through strict recruitment measures or requirements for eligibility (Kerbo, 2006:148-149). Businesses access cooperative economic and political power through corporate executives that represent the business at specific clubs or organisations. For these individuals, social networking offers the opportunity to advance their careers based on eligibility through association (Kerbo, 2006:154).

\section{Characteristics that Contribute to the Success of a Network}

The success of a business relationship is characterised by cooperation, collaboration, and shared information among the relevant partners. Long-term relationships are dependent on the actions of 
partners to affect mutual benefit (Moberg \& Speh, 2003:1). The characteristics also involve mutual participation and involvement or interaction by sharing information and building a reference of mutually beneficial exchanges (Peppers \& Rogers, 2004:36, 54).

Trust is another characteristic that contributes to the success of a network, which can be considered a highly valued human characteristic (Lindenfield \& Lindenfield, 2005:48) that drives the modern economy when combined with technology and innovation. Integrity is also an important characteristic that leads to reliability, and therefore trust in an individual's ability (Ciancutti \& Steding, 2001:211). Cooperation too is a significant characteristic and indicates social competency to build a reputation, which may lead to confidence in the specific idea, concept, individual or institution concerned (Markova, 2004:68-69). Competence, consistency, loyalty and openness are also noted by Nooteboom and Six $(2003: 63,129)$ as characteristics of successful networks.

The ability to provide or communicate specialised or sufficient information, expertise (Tullier, 2004:122), knowledge, skills, experience, education, contacts, personal characteristics, insights or any other exceptional ability (Kay, 2004:166) to the network may lead to added value in a specific situation (Rahman, 2006:82). This role or contribution needs to be acknowledged in order to enhance the quality of the network (Yeung, 2006:120).

In summary, a successful network is a strategic interaction in which all parties participate honestly and reciprocally work towards achieving mutual and individual trust, credibility, referrals and reliability to apply to different situations. A successful networker communicates his or her value and contributes toward the success of others. The following provides an overview of the research methodology used in the research.

\section{RESEARCH METHODOLOGY}

This study was conducted from an explorative and descriptive qualitative approach within a specific context in seeking to comprehend the perceptions of business owners and managers in the Gauteng Province in terms of their networking practices. A qualitative method (focus group discussions) provided data on the perceptions of the participants on networking and networking practices within such a context.

\section{Participants and Procedure}

Non-probability purposive voluntary sampling was used. Initially, an influential businessperson was invited to identify a group of participants within his networking environment. This led to further snowball sampling until five groups were established. Each businessperson identified their network members as possible participants in these groups. The participants were friends, colleagues or business acquaintances.

The inclusion criteria were that the participants had to: 1) be business owners and / or managers; 2) conduct business in the Gauteng Province; 3 ) be willing to share their opinions on and feelings regarding networking and networking practices; 4) be proficient in Afrikaans and English; 5) be prepared to be video- and audio taped; and 6) be prepared to be contacted afterwards for crossmember checking.

Five focus group discussions were conducted, which included forty-one participants (see Table 1 for participant description). The size of the focus groups varied from six to ten after fifteen to twenty potential participants had been invited. Saturation of results was reached after the first three group discussions, but a further two discussions were held to include additional female participants and participants from different racial groups, and to verify and add to the richness of the quotations already gathered. 
Table 1: Overview of Participants

\begin{tabular}{|c|c|c|c|}
\hline $\begin{array}{l}\text { Focus } \\
\text { group }\end{array}$ & Participants & Venue & Field or industry \\
\hline 1 & $\begin{array}{l}6 \text { entrepreneurs, } 2 \\
\text { managers }\end{array}$ & $\begin{array}{l}\text { Centurion } \\
\text { Academy }\end{array}$ & $\begin{array}{l}\text { Angel investment, finance, marketing, mining } \\
\text { software and technology development }\end{array}$ \\
\hline 2 & $\begin{array}{l}5 \text { entrepreneurs, } 3 \\
\text { managers }\end{array}$ & $\begin{array}{l}\text { Centurion } \\
\text { Academy }\end{array}$ & $\begin{array}{l}\text { Business profile development, construction, } \\
\text { educational products, marketing and software } \\
\text { technology }\end{array}$ \\
\hline 3 & $\begin{array}{l}2 \text { entrepreneurs, } 7 \\
\text { managers }\end{array}$ & $\begin{array}{l}\text { Manhattan } \\
\text { Office Park }\end{array}$ & $\begin{array}{l}\text { Research and development, as well as } \\
\text { technology }\end{array}$ \\
\hline 4 & $\begin{array}{l}3 \text { entrepreneurs, } 7 \\
\text { managers }\end{array}$ & CSIR & $\begin{array}{l}\text { Angel investment, finance, marketing, patent } \\
\text { law and technology development }\end{array}$ \\
\hline 5 & $\begin{array}{l}1 \text { entrepreneur, } \\
5 \text { managers }\end{array}$ & $\begin{array}{l}\text { Centurion } \\
\text { Academy }\end{array}$ & $\begin{array}{l}\text { Accounting, design, educational products, } \\
\text { finance, marketing and product development }\end{array}$ \\
\hline Total & 41 & & \\
\hline
\end{tabular}

\section{Data Collection}

Participants were invited to attend the focus group discussions at a central venue, scheduled for 7:00 am so that the discussion would not consume too much time in their normal day. Attention was given to the environment in which the discussions were conducted in order to ensure that the participants were comfortable and relaxed, by providing an air-conditioned venue and serving a light breakfast before the discussions. The venues included boardrooms and privately booked coffee shops at which a 'do not disturb' sign was placed outside the door in order to ensure privacy and to keep interruptions to the minimum. The researcher started the discussions with a friendly introduction and explanation of the process and then the participants introduced themselves. The participants were asked to complete a consent form, authorising video- and audio taping of the discussions and use thereof following the discussions, as well as a brief demographic questionnaire. Participants were ensured of the confidentiality of the information and that the information would remain anonymous outside the focus group context. Participants were informed that they could withdraw at any stage should they feel uncomfortable for any reason.

The same agenda was set for each focus group discussion, which included the following questions: 1) What do you consider networking?; 2) Explain the difference between the approach to internal and external networking practices; 3) What elements form part of networking?; 4) Identify the elements of networking success and of networking failure; and 5) Would you share an example of an outstanding personal networking experience?

Various techniques were used during the focus group discussions to elicit and verify information, such as probing (asking for more information on what had just been said), paraphrasing (restating the participants' words in other words with similar meaning), minimal responses (occasional nodding and verbal responses such as uh-hm, yes, I see), clarification (seeking clarification from participants regarding unclear statements), reflection (examining something important the participant had said in order to probe him or her to expand on this), and summarising (verbally reviewing the participant's ideas, thoughts and feelings in order to ensure that interpretation was correct).

Field notes were taken during the focus group discussions (Breakwell, 2004:346), which included: 1) contextual notes (notes on the venue, setting and other important aspects related to context); 2) personal notes (reflections on the researcher's own experiences and observations); and 3) observational notes (notes on circumstances and situational happenings during the focus group discussions that might have influenced the discussions) (Holloway \& Wheeler, 2002:87). The field notes assisted the recall of participants' responses and the context of the discussions, and enabled 
the later exploration of the process of the focus group discussions in order to reduce the loss of data during the study.

\section{Data Analysis}

Verbatim transcriptions (De Vos, Strydom, Fouche \& Delport, 2005:312) were made of the video and audio recordings of the focus group discussions. The field notes from the five different focus group discussions were analysed separately through the theme approach (Creswell, 1994:155). Each theme was then labelled using the NVivo 2.0 qualitative software programme. The theme approach entailed the following steps: Firstly, the transcript information was grouped into three columns: the researcher's thoughts, the actual text and the themes as they emerged. Then, NVivo was used to group the identified themes. The identified themes were thereafter grouped into main, sub- and additional themes and relationships were sought among them (Daymon \& Holloway, 2002:233). Fragmented sub-themes were placed into focused main themes. The direct quotations were then converted into scientific language and the precise wording was used as support. Next, fragments of the content were sent to different participants for member checking to ensure trustworthiness of the findings. Finally, a co-coder was used to ensure that the themes and sub-themes were correctly identified. A third independent researcher was contacted to resolve any discrepancies. Discussions were continued until consensus was reached.

\section{Trustworthiness}

The trustworthiness of the findings was ensured by using Guba's model (Guba, 1981; Lincoln \& Guba, 1985) to assess the trustworthiness of the qualitative data. Truth-value, transferability, consistency and neutrality were used as criteria to assess the trustworthiness of the findings. Table 2 provides a summary of the strategies implemented in order to ensure trustworthiness of the data and the appropriate application for each strategy in this study.

Table 2: Trustworthiness of the Study

\begin{tabular}{|l|l|}
\hline Criteria value strategy: & Application \\
\hline $\begin{array}{l}\text { Truth vedibility: Triangulation } \\
\text { Preer examination }\end{array}$ & $\begin{array}{l}\text { Thederators, field notes were taken and the relevant theory } \\
\text { was reviewed before and after the discussions. } \\
\text { The research proposal was reviewed by a panel of peer } \\
\text { reviewers, and the agenda for the focus group discussions } \\
\text { was evaluated by an expert. } \\
\text { An extended period was spent with the participants and } \\
\text { they were contacted over time for member-checking } \\
\text { purposes. } \\
\text { Various researchers were involved in the process. Field } \\
\text { notes, and video and audio recordings were taken to } \\
\text { ensure that all observations and experiences were } \\
\text { captured. }\end{array}$ \\
Reflexive analysis & $\begin{array}{l}\text { Various techniques for focus group discussions and good } \\
\text { communication practices were used in the process, } \\
\text { including paraphrasing, summarising, repeating and } \\
\text { expanding. } \\
\text { Snowball sample }\end{array}$ \\
\hline $\begin{array}{l}\text { Transferability strategy: } \\
\text { Interview techniques } \\
\text { demographic data sample to }\end{array}$ & $\begin{array}{l}\text { All the researchers analysed the data and consensus was } \\
\text { reached on the identified themes. } \\
\text { Auditing was made possible by video and audio recordings } \\
\text { of the focus group discussions. }\end{array}$ \\
\hline $\begin{array}{l}\text { Consistency strategy: } \\
\text { Code-recode } \\
\text { Dependability audit }\end{array}$ &
\end{tabular}




\begin{tabular}{|l|l|}
\hline $\begin{array}{l}\text { Dense description of research } \\
\text { methods }\end{array}$ & $\begin{array}{l}\text { A detailed description of the research methodology was } \\
\text { included to ensure the research process could be } \\
\text { repeated. }\end{array}$ \\
\hline $\begin{array}{l}\text { Neutrality strategy: } \\
\text { Confirmability audit }\end{array}$ & $\begin{array}{l}\text { Transcriptions and field notes taken during the focus group } \\
\text { discussions can be made available for auditing purposes. }\end{array}$ \\
\hline
\end{tabular}

Source: Krefting (1991:214-222)

\section{Ethical Aspects}

The research methodology was approved by the North-West University Ethics Committee. Confidentiality and the participants' right to privacy (Cooper \& Schindler, 2003) were ensured by allowing only authorised persons access to the video and audio recordings, and ensuring that no names or identities were mentioned or disclosed in the study. The participants gave informed consent, participated voluntarily, and were free to withdraw from the study at any time. The researcher acted in a truthful and respectful manner in order to establish an ethical environment (Struwig \& Stead, 2001).

\section{RESULTS}

The findings of the focus group discussions are reported by summarising the five main themes that emerged from the data (see Table 3). Participants' words as recorded during the focus group discussions are included to enrich the findings by providing a way in which the thoughts and conceptualisation of the participants can be better understood (Delport \& Fouche, 2005:168). The appropriate findings are supported by the relevant literature to confirm the findings, dispute them or provide theoretical grounding for unique findings.

\section{Table 3: Summary of main themes}

\begin{tabular}{|l|l|}
\hline Perception 1 & Networking as a skill versus a natural ability \\
\hline Perception 2 & Networking needs a motivating factor \\
\hline Perception 3 & Networking loci \\
\hline Perception 4 & Relationships determine the character of the network \\
\hline Perception 5 & Specific characteristics are important in networks \\
\hline
\end{tabular}

\section{Perception 1: Networking as a Skill versus a Natural Ability}

Participants indicated that they perceive networking as a skill and something that not everybody can do equally well. It became apparent that networking skills are very important and that most people lack these skills because it is perceived as a natural skill that one either has or does not have. Supportive quotations include: "But it [networking] is not a natural thing that you are just born with." and "Most people in SA [South Africa] aren't born with the ability to network. It is not easy for anybody to just go out to somebody and start speaking to him. It is a skill you need to be taught." Literature confirms the notion that networking is a skill and natural feeling to utilise networking as a key skill to reach out to others beyond the networker's world and the scope of acquaintances (Zweibel, 2006).

The literature confirms, as perceived by the participants, that networking is important and emphasises the importance of developing training courses to develop these skills, since schools, tertiary institutions and government provide insufficient training. Training for business people should be aimed at developing networking as a formal structured business activity (Takash, 2004:24). According to Nierenberg (2005:3), network training should also enable business managers and entrepreneurs to make acquaintances with key people and expand the business, in other words by increasing the networker's own value to others (Taylor, 2006:48-53). 


\section{Perception 2: Networking Needs a Motivating Factor}

The participants mentioned that they perceive networking as something that is motivated by a specific need for action or desire to exploit actual value. The participants distinguished between business and personal motivations, but in both instances, they feel that a mutual interest is essential prior to considering engaging in networking. The following quotation supports this finding: "For me there are also two types, in my personal setup, I trust a few, and then I have a few business contacts, which is another relationship, because then I look for mutual opportunity, specific needs and something that we want to address together." Soanes (2002:756) and Gruszczynski (2005) define a network as a group of people that are connected together to interact or work as a team. De Man (2004:165) defines networks as selected sets that interact on a direct and indirect basis to obtain strategic competitive advantages. There appears to be numerous possibilities of whom to include in networks (whether business acquaintances, suppliers, friends or family), as long as these networking efforts (regardless of frequency, control or length of relationships) are aimed towards mutual interest (Webster, 1976:1519, 1520) or to enhance and develop further connections (Soanes, 2002:756). The motivation to engage will be enhanced accordingly with regard to the value that each member can bring to the network (McGrath \& Sparks, 2005:45).

The participants mentioned business and personal reasons as motivations to enter into networking relationships. In terms of business networks, the participants mentioned that they feel that should they decide not to network with certain role-players in business, they might lose business. The following quotation supports this finding: "I can remember complaining bitterly because the chief executives of the company didn't have the right networks to get the orders they feel they deserved, so clearly if you don't have 'networking' - whatever it is, relationships - you lose serious business. I think we can agree on that." Salmon (2004:14) supports the finding, stating that networking can be used to gain a better position in business in order to gain access to favourable connections or information.

Personal motivations to network mentioned by the participants include the personal satisfaction derived from assisting someone and adding value to that person, personal support and adding value to one's personal life. The following quotations support personal reasons for networking: "Personal satisfaction or personal gratification, so you know if I do something for him, I will get something in return." and the motivation to add some kind of value to that person: "I want to build a relationship, because I exist and I want it. I build relationships, because I enjoy it and because there is value." Casciaro and Lobo (2005:92) confirm this, by stating that people are motivated to partner with other people who have similar or higher competencies in order to add value to their own lives, or to add to their abilities and competencies, and because they are likeable and their personalities are compatible.

\section{Perception 3: Networking loci}

All participants were of the opinion that networking is essential, but had different opinions regarding networking loci. The common perception among participants is that one is never too young to start developing the necessary networking skills and to start building a personal network of contacts and relationships: "When do you start to network? As soon as possible." Most of the participants also indicated that they only started building a network later on and that several opportunities had been lost because they did not realise the actual value of developing and maintaining existing networks or relationships.

The participants specifically mentioned the following networking loci: in families, at school, even at nursery school level (whether intentionally or unintentionally), at university, at work and in specific settings, such as cultural events, networking events, social groups and chambers of commerce. Nursery school as a possible networking locus was not supported in the literature, and is therefore a significant contribution. The chamber of commerce as a networking locus was discussed with mixed reaction, with several participants feeling that it is a waste of time: "When I decided to join the chamber of commerce, I experienced it as a place for insurance agents, estate agents and other 
people that want to suck something out of you. So if they ask you to invite your friends you cannot do that to them", while others relied on this organised event to network: "We [want to be] part of something, a group of people with similar business interests, professionals with a similar skills set."

Several researchers refer to schools and university (Tullier, 2004; Slesinger, 2005; Kerbo, 2006), the workplace (Paul \& Kaltenbach, 2004:32), cultural events, alumni organisations, sport or health clubs, parent associations, interest groups, involvement in local community projects and volunteer work (Lindenfield \& Lindenfield, 2005:233), and networking events (Wolk \& Pont, 2005; McGrath \& Sparks, 2005) as networking loci. In short, Biadasz (2005:23) combines this, stating that a networker should include everyone in his or her professional and personal life that he or she has met from birth up to the present day in all his or her networking efforts.

\section{Perception 4: Relationships Determine the Character of the Network}

The participants mentioned that relationships are the cornerstone of successful networking and that people respond to the way they are treated, more than to the actual offering. The participants mentioned that they feel people buy relationships not goods and respond to the human attraction or shared interest: "The concept of networking as an informal, everyone-does-it, almost as a human need that you find in all relations and on all levels, that is the relationships that we build on." Social, referral and business networks were identified as areas in which people tend to satisfy their need to network consciously and unconsciously. Each of these areas is discussed below.

\section{Social Networks}

The participants indicated that they perceive family, friends and shared interest groups as part of their personal, social relationship network. This network appears to be characterised by elements of a strong need for support, love, acceptance and common interests. The following quotation supports this finding: "I have a personal network and it is a fantastic powerful network. It is a support base, it is friendships and you know the family of friends, but it is not as if I want to do business with them." This finding is supported by Armstrong and Yee (2001:63-68), who state that personal, social relationships are built on friendships, which are filled with peace, love and closeness (Kahn, 1989:207) between two people as a sort of kinship (Gounaris, 2005:130) or common interest that binds people socially or keeps them connected (Frazier \& Niehm, 2004:27).

\section{Business Networks}

The participants indicated that certain relationships are specifically built for conducting business. These relationships are aimed at accessing business opportunities and improving business performance, effectiveness and overall competitive advantage. The following quotation supports this: "Absolutely, I think it depends on the network, it can be a meaningful network or maybe we should talk about a network in a business context, there are naturally other networks as well. It is not as if I want to do business with everyone. I know people that do business with everyone." According to the literature, networking connections include a web of interconnected actors or businesses (Vervest, Van Heck, Preiss \& Pau, 2005:4). These connections combine their value to achieve a common purpose or higher result (Gruszczynski, 2005), which may include cooperative relationships among businesses with the same focus, motivation and skill to achieve the shared goals of the members (Lipnack \& Stamps, 1993:7; Lundan, 2002:9).

\section{Perception 5: Specific Characteristics are Important in Networks}

The participants mentioned that a network is composed of people who possess certain personal characteristics in order to be successful in their networking attempts. The mentioned characteristics and quotations supporting these are given below.

The participants perceived responsibility as an important characteristic of a successful network. Networks have a reciprocal nature, which implies that each of the participating role-players in the 
network is expected to assume responsibility for his or her actions and contributions. The participants mentioned that they perceive accountability of every network member for his or her individual inputs, and development and maintenance of network relationships as another important characteristic of a successful network. The participants highlighted credibility as one of the most important characteristics of a successful relationship network and mentioned that credibility is built over time, through experience and continuous performance. The following quotation supports these three characteristics of success: "You can only have a network if you take responsibility, accountability. Those people do what they have said they would do. But it builds on credibility you know: the more the credibility, the more you will use those people again."

These three characteristics are discussed in the literature as associated with trust or trustworthiness. For example, Pepper and Rogers (2004) distinguish between credibility (believable words and truthfulness) and reliability (predictable and familiar actions). The participants mentioned trust as being an essential factor of the success of a network. The following quotations support this: "In the end it is all about good relationships with people you trust. Respect and trust." and "Trust takes time to develop and is only achieved by a list of previous testimonials."

The participants perceive the relationship content as a personal experience and therefore each individual defines trust from their own perspective, making it a highly complex issue. The following quotation supports this: "A person trusts you when he has an experience with you, you help him with something and it only happens when you do that bonding on a very close level." In the literature, trust is referred to as the extent of the other role-player's belief that the expectation or obligation will be fulfilled and that trust is present in a valued relationship (Sargeant, Ford \& West, 2006:156).

Another perceived characteristic of success mentioned by the participants is resourcefulness. Resourcefulness is the ability to contribute positively to a network in terms of skill, expertise, knowledge or information access or to bring relevant parties together and to add value to a relationship. The following quotation supports this: "I still believe that you have to build trust relationships and the urgency of success in business is to understand the other one's needs to be networking and its success lies in the information and adding value to one person by understanding the other person." Detail regarding the way a networker could be a resource and the extent to which a networker needs to be knowledgeable or contribute to the success of others was not expressively found in the literature. That resourcefulness is important in a network is discussed by Lindenfield and Lindenfield (2005:14,59), who state that a networker needs to be resourceful to others and this can be achieved by offering assistance.

\section{DISCUSSION AND CONCLUSIONS}

Much of the literature on networks and networking is European and American oriented, and only a few sources seek to investigate the South African networking environment. Each cultural and societal environment has its own practices and approaches to networking. The explorative research results reported in this study confirm some of the common findings as discussed in international literature, but some findings are unique and distinctly characterised by influences of a South African nature.

One of the findings suggest that in general people appear to be motivated to enter into networking relationships for either business or personal gain. The uniqueness and significance of this finding in a South African context is that the participants feel that there is a strong difference between the two, and several participants implied that they do not wish to conduct business with their family or friends. Others mentioned that they require a record of rapport and references to enter into a business relationship with another person. This indicates that people are motivated by different factors and the expected result, value or personal gain guides the decision to enter into the relationship or the context of the relationship. 
The networking loci mentioned is places in all spheres of an individual's life. The participants stated that some started networking at school, at university, at work, cultural, social and sports events, and specific networking events. Several of the participants stated that it would have been beneficial to them to start networking in nursery school to build references and networking relationships. Several of the participants stated that they do not feel that the chamber of commerce is a constructive networking locus for building meaningful business relationships. This contradicts the most widely cited literature regarding the advantages of chambers of commerce as networking loci in First World countries, such as the UK and USA. It may thus be concluded that chambers of commerce are not as effective within a South African context as would be expected, and that a new strategy should be adopted or a new form of organisation should be developed.

Successful networks have specific characteristics that contribute to the well-being of the relationships in the network. The characteristics mentioned in the literature and by the participants include trust, responsibility, accountability, credibility and bringing something of oneself in terms of personality. These appear to be the key characteristics of successful relationships and therefore successful networks.

\section{RECOMMENDATIONS}

South African managers should acknowledge the unique challenges and richness of a diverse South African society and the relevance of this to networking in a business and with other businesses. A business environment in which there are high levels of trust, integrity, credibility, competency and the opportunity to add value should be created and nurtured to enhance networking practices, communication and overall business success.

Training courses in networking to develop this vital skill should be provided to workers. These courses should concentrate on existing literature and theories, but should include issues, approaches and practical examples of importance to a South African audience. Governmental and educational institutions should prioritise networking skills as essential business tools and provide the necessary support to develop these courses.

This study should be extended to include a larger sample representative of the South African population. Comparative studies among different cultures (and thus cultural practices) and different countries should be conducted. 


\section{REFERENCES}

Anderson, M.H. 2008. Social networks and the cognitive motivation to realize network opportunities: a study of managers' information gathering behaviours. Journal of Organizational Behavior, 29(1):5178, Jan.

Armstrong, R.W. \& Yee, S.M. 2001. Do Chinese trust Chinese? A study of Chinese buyers and sellers in Malaysia. Journal of International Marketing. 9(3): 63-86.

Baker, W.E. 2000. Networking smart. How to build relationships for personal and organisational success. Lincoln, NE: iUniverse.com.

Bawa, N. 2006. Family-owned business in South Africa: Local enterprise responses by South African Indian family-owned business. Urban Forum, 17(2):167-198, Apr.

Biadasz, P. 2005. More leads: The complete handbook for tips groups, lead groups and networking groups. New York: iUniverse, Inc.

Boe, A. 1994. Networking success: How to turn business \& financial relationships into fun \& profit. Deerfield Beach, FL: Health Communications.

Boe, A. \& Youngs, B.B. 1989. Is your "net" working?: A complete guide to building contacts and career visibility. New York: John Wiley \& Sons.

Borgatti, S.P. \& Foster, P.C. 2003. The network paradigm in organizational research: A review and typology. Journal of Management, 29(6):991-1013.

Brass, D.J., Galaskiewicz, J., Greve, H.R. \& Tsai, W. 2004. Taking stock of networks and organisations: A multilevel perspective. Academy of Management Journal, 47(6):795-817.

Bridgewater, S. \& Egan, C. 2002. International Marketing Relationships: profitable marketing relationships series. New York: Palgrave.

Breakwell, G.M. ed. 2004. Doing Social Psychology Research. $1^{\text {st }}$ ed. Oxford: Blackwell.

Casciaro, T. \& Lobo, M.S. 2005. Competent jerks, lovable fools, and the formation of social networks. Harvard Business Review, 83(6):92, Jun.

Ciancutti, A.R. \& Steding, T.L. 2001. Built on Trust - Gaining Competitive Advantage in Any Organisation. Chicago, IL: Contemporary Books.

Cohen, D. \& Prusak, L. 2001. In Good Company. Boston, MA: Harvard Business School Press.

Cooper, D.R. \& Schindler, P.S. 2003. Business research methods. $8^{\text {th }}$ ed. New York: McGraw-Hill.

Crawford, P.I. \& Hafsteinsson, S.B. eds. 1996. The construction of the viewer: proceedings from NAFA 3. Denmark: Intervention Press (In association with the Nordic Anthropological Film Association).

Creswell, J.W. (1994). Research design: Qualitative and quantitative approaches. London: Sage. 
Cross, R., Liedtka, J. \& Weiss, L. 2005. A Practical Guide to Social Networks. Harvard Business review, 83(3):124-132, Mar.

Czerniawska, F. \& Potter, G. 1998. Business in a Virtual World - Exploiting Information for Competitive Advantage. London: MacMillan Press Ltd.

Darley, W.K. 2003. Public policy challenges and implications of the Internet and the emerging ecommerce for sub-Saharan Africa: A business perspective. Information Technology for Development, $10: 1-12$.

Daymon, C. \& Holloway, I. 2002. Qualitative research methods in public relations and marketing communications. London: Routledge.

De Klerk, S. \& Kroon, J. 2007. Networking in South African businesses. Management Decision, 45(1):89-103.

De Man, A. 2004. The networked economy: Strategy, structure and management. Cheltenham: Edgar Elgar.

Delport, C.S.L. \& Fouche, C.B. 2005. Quantitative data-collection methods. (In: De Vos, Strydom, Fouche \& Delport, Research at Grass Roots for the Social Sciences and Human Service Professions). $3^{\text {rd }}$ ed. Pretoria: Van Schaik Publishers.

Denner, M. \& Oosthuizen, H. 2008. The strategic positioning and configuration of national mapping organisations as enablers of economic and social growth in South Africa. South African Journal of Business Management, 39(3):41-55, Sep.

De Vos, A.S., Strydom, H., Fouche, C.B. \& Delport, C.S.L. 2005. Research at grass roots for the social sciences and human service professions. $3^{\text {rd }}$ ed. Pretoria: Van Schaik.

Ford, I.D. 1998. Managing business-relationships. Chichester: John Wiley \& Sons.

Frazier, B.J. \& Niehm, L.S. 2004. Exploring business information networks of small retailers in rural communities. Journal of Developmental Entrepreneurship, 9(1):23-40, Apr.

Garton, L., Haythornthwaite, C. \& Wellman, B. 1997. Studying online social networks. [Web:] http://www.ascusc.org/jcmc/vol3/issue1/garton.html [Date of access: 01 Nov 2004].

Gemünden, H.G., Ritter, T. \& Walter, A. eds. 1998. Relationships and networks in international markets. Oxford: Pergamon.

Gounaris, S.P. 2005. Trust and commitment influences on customer retention: insights from business-to-business services. Journal of Business Research, 58(2):126-140, Feb.

Grandori, A. 1999. Interfirm networks: Organization and industrial competitiveness. London: Routledge.

Gruszczynski, W. 2005. Small enterprises' cooperation groups. Importance of personal relationships in small enterprises' cooperation. (Paper delivered at the $4^{\text {th }}$ International Conference of Entrepreneurship - Employment and Beyond, September 8-9, 2005. Sodertörns Högskola University College, Stockholm Sweden).

Guba, E.G. 1981. Criteria for assessing the trustworthiness of naturalistic inquiries, Educational Resources Information Centre Annual Review Paper, 29, 75-91. 
Hadjikhani, A. \& Thilenius, P. 2005. Non-business actors in a business network: A comparative case on firms' actions in developing and developed countries. Elsevier, Amsterdam: Oxford.

Holloway, I. \& Wheeler, S. 2002. Qualitative research in Nursing. $2^{\text {nd }}$ ed. Oxford: Blackwell. Jones, O. \& Tilley, F. eds. (2003). Competitive advantage in SMEs - Organising for innovation and change. West-Sussex: John-Wiley \& Sons.

Kahn, J.E. ed. 1989. Reader's Digest: reverse dictionary. London: The Reader's Digest Association.

Kay, F. 2004. Brilliant business connections - How powerful networking can transform you and your company's performance. Oxford: How to Books.

Kerbo, H.R. 2006. Social stratification and inequality: class conflict in historical, comparative and global perspective. $6^{\text {th }}$ ed. New York: McGraw-Hill.

Koniordos, S.M. ed. 2005. Networks, trust and social capital - theoretical and empirical investigations from Europe. Hants, UK: Ashgate.

Krefting, L. 1991. Rigor in qualitative research: The assessment of trustworthiness.

American Journal of Occupational Therapy, 45(30): 214-222, Mar.

Lincoln, Y. S., \& Guba, E. A. 1985. Naturalistic inquiry. London: Sage.

Lindenfield, G. \& Lindenfield, S. 2005. Confident networking for career success and satisfaction. London: Piatkus.

Lindsay, D. 2005. Cracking the networking code. $2^{\text {nd }}$ ed. Plano, TX: World Gumbo.

Lipnack, J. \& Stamps, J. 1993. The teamnet factor - Bringing the power of boundary crossing into the heart of your business. Essex Junction, VT: Oliver Wright.

Lundan, S.M. ed. 2002. Network knowledge in international business. Cheltenham: Edgar Elgar.

Markova, I. ed. 2004. Trust and democratic transition in post-communist Europe. Oxford: Oxford University Press.

McGrath, R. Jnr \& Sparks, W.L. 2005. The importance of building social capital. Quality Process. 38(2):45-50, Feb.

Misner, I.R. \& Morgan, D. 2000. Masters of networking: Building relationships for your pocketbook and soul. Marietta, GA: Bard Press.

Moberg, C.R. \& Speh, T.W. 2003. Evaluating the relationship between questionable business practices and the strength of supply chain relationships. Journal of Business Logistics. 24(2):1-19.

Morris, M., Bessant, J. \& Barnes, J. 2006. Using learning networks to enable industrial development: Case studies from South Africa. International Journal of Operations \& Production Management, 26(5):532-557.

Moyer, D. 2005. Give to get. Harvard Business Review, 83(10):160, Oct.

Nierenberg, A.R. 2005. Making New Contacts. The American Salesman, 50(4):3-8. Apr. 
Nooteboom, B. \& Six, F. eds. 2003. The Trust Process in Organizations: Empirical Studies of the Determinants and the Process of Trust Development. Cheltenham, UK: Edgar Elgar Publishing.

NVIVO. 2002. Introducing Nvivo: a workshop handbook. Nvivo 2.0. QSR International. www.qsrinternational.com.

Paul, K. \& Kaltenbach, P. 2004. Networking beyond the Business Cards. Catalist (2002): 32, Sept/Oct.

Peppers, D. \& Rogers, M. 2004. Managing customer relationships: a strategic framework. New Jersey: John Wiley \& Sons.

Pillay, U. 2004. Towards alternative conceptions of local economic reform in the developing world: The case of South Africa. South African Geographical Journal, 86(1):39-43.

Rahman, H. ed. 2006. Empowering marginal communities with information networking. London: Idea Group.

Salmon, M. 2004. Super networking - Reach the right people. Build your career network, and land your dream job - now! Franklin Lakes, NJ: Career Press.

Sargeant, A., Ford, J.B. \& West, D.C. 2006. Perceptual determinants of nonprofit giving behavior. Journal of Business Research, 59(2):155-165, Feb.

Slesinger, L. 2005. A recruiter's guide to mining your network. Association Management Washington, 57(2): 40-44, Feb.

Soanes, C. ed. 2002. Compact Oxford English Dictionary of Current English. $2^{\text {nd }}$ ed. Oxford: Oxford University Press.

Struwig, F.W. \& Stead, G.B. 2001. Planning, designing and reporting research. Cape Town: Pearson Education South Africa.

Takash, J. 2004. Networking success: Discover the tools you need to get to the top. Business Credit, 106(4):24-25, Apr.

Taylor, J. 2006. Monster careers. Networking. New York: Penguin Group.

Templeton, T.L. 2003. The referral of a lifetime: the networking system that produces bottom-line results... every day. $1^{\text {st }}$ ed. San Francisco, CA: Blanchard Family Partnership.

Tullier, L.M. 2004. Networking for job search and career success. $2^{\text {nd }}$ ed. Indianapolis, IN: JIST Works.

Tomak, K. \& Keskin, T. 2008. Exploring the trade-off between immediate gratification and delayed network externalities in the consumption of information goods. European Journal of Operational Research, 187(3):887-902, Jun.

Yeung, R. 2006. The rules of networking. London: Cyan Communications.

Uzzi, B. \& Dunlap, S. 2005. Managing yourself - how to build your network. Harvard Business Review, 83(12):53-60, Dec. 
Van Winkelen, C. 2003. Inter-Organisational Communities of Practice. [Web:] http://www.elearningeuropa.info/index.phpl [Date of access: 5 Apr 2006].

Vervest, P., Van Heck, E., Preiss, K. \& Pau L. eds. 2005. Smart business networks. Berlin, Germany: Springer.

Visagie, U. 2006. Verbal communication and e-mail with business person and networking expert. [Email to unre@nexts.co.za.] Pretoria. (Original notes in possession of the author.)

Webster, N. 1976. Webster's third new international dictionary of the English language: unabridged / editor in chief, Philip Babcock Gove and the Merriam-Webster editorial staff. Springfield, MA: Merriam.

White, H. 2004. Networking for business success - Quick tips for busy people. London: Writersprintshop.

Wickham, P.A. 2004. Strategic entrepreneurship. $3^{\text {rd }}$ ed. Essex: Pearson Education.

Wolk, D. \& Pont, J. 2005. At social job sites, it's who you know. Workforce Management. 84(5):52, May.

Zweibel, B. 2006. How to improve your networking skills: Gottagettacoach! quest career services. [Web:] http://www.questcareer.com/networking skills.htm [Date of access: 18 May 2006]. 